\title{
The EU Regulatory Competition in Asylum Law
}

\begin{abstract}
This paper deals with the principle of subsidiarity in asylum law. It exposes some of the most important 'push' factors that have been considered by the European Union (EU) as arguments for the centralisation of asylum law. Through the application of an economic approach, this text examines the need for harmonization of asylum standards to reach the goal established in Article 5 of the Treaty on European Union. An economic methodology is used to investigate the application of the subsidiarity principle by considering some of the most important economic criteria for both centralisation and decentralisation, and by applying the findings to the asylum law. Specifically, this paper considers the Tiebout model, the problem of the 'race to the bottom', the reduction of transaction costs, and the importance of the protection of refugee human rights. These theories are commonly used in the cases of a specific issue with a transboundary nature, which produces [negative] international externalities. In addition, they reflect the significance of equal conditions within the EU Member States as well as the role of the EU as a sui generis organisation protecting human rights. It should be noted that this paper does not deal with the basic normative question of whether or not refugees deserve protection, but it aims to expose the advantages and disadvantages of an EU asylum policy. In its conclusion, the paper discusses the advantages of a centralised EU policy that also allows, within certain conditions, some type of competition between the Member States.
\end{abstract}

KEYWORDS: Asylum law, refugee protection, EU competence, subsidiary principle

RECEIVED 23 January 2017; ACCEPTED 24 May 2018.

\section{INTRODUCTION}

For more than a decade, the European Union (EU) has received a considerable number of irregular migrant flows. Although the number of irregular migrants decreased significantly during 2018 as compared to 2016 and 2017, the irregular arrival of migrants in the Mediterranean Sea remains a controversial political issue (Koka and Veshi, 2019).

This problem raises the main research question regarding the optimal level of the EU centralization of asylum policy. In this manuscript, the optimal level is understood to be the creation of the highest benefits for the protection of refugee rights considering the interests of all the EU Member States. This paper does not aim to examine the literature regarding the advantages and disadvantages of competition between legal orders in general; it deals with the principle of subsidiarity in asylum law, which was formally introduced in the Single European Act of 1992. In particular, this manuscript studies the need for a harmonisation of asylum standards in order to achieve the goal established in Article 5 of the Treaty on European Union (TEU) through employing an economic approach. Thus, this paper uses an economic methodology to investigate the application of the subsidiarity principle in asylum law. In addition, it examines the current literature regarding the application of this principle in public law.

The majority of classical literature has applied a human rights approach to the refugee protection (Fischer-Lescano, Löhr, and Tohidipur, 2009; Goodwin-Gill, 2007; Hathaway, 2005; Roberts, 2004; Bailliet, 2003; and Lauterpacht and Bethlehem, 2003). This approach is also based on the main case-law of the European Court on Human Rights (ECtHR) (application nos. 27765/09 3394/03, and 55721/07), the European Court of Justice (Joined Cases C-391/16, C-77/17 and C-78/17), as well as the main documents published by the United Nations High Commissioner for Refugees (2007, 2004, and 1997), and the Committee against Torture of the United Nations (2006). Nevertheless, in recent years, the literature dealing with asylum policy using economic methods has expanded. In particular, several empirical studies have been conducted in order to expose the main variables that impact refugee decision-making process (Gilbert and Koser, 2006; Neumayer, 2005; Day and White, 2002), their impact on the labour market (Rosholm and Vejlin, 2010; Cortes, 2004; Dustmann, 1997; Card, 1990; Rivera-Batiz, 1990) or national security (Randahl, 2016; Choi and Salehyan, 2013; Milton, Spencer, and Findley, 2013; Mogire, 2009) of the host countries.

1 Chair of the Social Sciences Research Center; Chair of the Erasmus+ Jean Monnet EU Center of Excellence; University of New York Tirana, Tirana, Albania denardveshi@unyt.edu.al 
In addition, in the case of the EU asylum policy, the literature agrees that the minimum-standard regime is more beneficial than the fixed-standard regime (des Places, Barbou, and Deffains, 2003) since national governments would have some policy discretion in ruling asylum laws (Esty, and Geradin, 2001) while maintaining the opportunity for each country to maximise the sum of their national net benefits (Monheim-Helstroffer and Obidzinski, 2010). Although other scientific contributions have exposed the advantages and disadvantages of an EU asylum policy by using economic methods (Fernández-Huertas Moraga and Rapoport, 2015; Monheim-Helstroffer and Obidzinski, 2010; des Places and Deffains, 2003), by also considering the public choice theories of federalism such as the Swiss and the Canadian models, this paper synthesizes, reviews, and analyses some of the most important economic theories - such as the 'race to the bottom', the Tiebout argument (especially, the evolutionary efficiency and the importance of information costs), the Coasean bargaining, the risk of strategic behaviour, the 'free-riding' incentive, and transaction costs - in regard to asylum law. These theories are commonly used in the cases of transboundary nature of a specific issue, which produces international (negative) externalities (Faure, 2001; and Van den Bergh, 1994). Furthermore, it should be emphasized that this paper deals with the optimal level of the EU centralization of asylum policy in general and does not focus solely on the current refugee crisis. Therefore, this contribution can also be used in the case of future migration crisis (i.e., climate refugees).

This paper comprises three sections. Section II presents the three main 'push' factors shown by the EU as arguments for the centralisation of asylum law. These factors shall be understood as the main different reasons for an EU competence in asylum law. Section III considers the criteria for centralisation and decentralisation, again with regard to asylum issues. Specifically, section III considers the Tiebout model, the problem of the 'race to the bottom', ${ }^{2}$ the reduction of transaction costs, and the importance of the protection of human rights. In the conclusions, the paper considers the main literature by suggesting the advantages of a centralised EU policy that, within certain conditions, allows some type of competition between the Member States.

\section{EU ASYLUM POLICY: HARMONIZATION OF COMMON STANDARDS}

Until now, the EU has enacted different regulations and directives of asylum law in addition to rethinking it to suit the current refugee crisis (Price, 2009). The EU has not only established common European asylum standards but has also harmonised the asylum procedural rules. Clear examples of common European law defining the asylum standards are the Reception Conditions Directive (Directive 2013/33/EU) and the Qualification Directive (Directive 2011/95/EU). In addition, procedural harmonisation is set out in the Asylum Procedures Directive (Directive 2013/32/EU) and the Dublin Regulation (Regulation (EU) No 604/2013), which prescribe fairer, quicker, and higher quality asylum decisions determined by the responsible EU Member State.

The EU has set out different reasons for legislative action at the European level with respect to asylum law. Here, this paper analyses the three main 'push' factors that have been considered by the EU through the application of economic methods and legal reasoning. While the first two 'push' factors are directly connected with the economic interpretation of the subsidiarity principle, the third one applies a human rights approach.

First, the transboundary nature of the refugee crisis is closely connected with the problem of (negative) externalities. As known, according to the core Law and Economics literature, the protection of refugees is considered as an international public good (Betts, 2003; Bubb et al., 2011; Kremer et al., 2011), since it produces non-excludable and indivisible benefits (Thielemann, 2018). More specifically, the individual State's choice entails positive or negative externalities for third countries because it directly affects the flow of migration (Bubb, 2011). Perhaps when significant international (negative) externalities exist, there will be some convergence of national laws towards restricting refugee policies. Indeed, the French asylum reform of 1991 resulted in an increase of asylum seekers moving to Germany (Rotte, 1996). The EU has tried to tackle this problem with the Dublin regulation, which defines the State responsible for examining the application and clarifies the rules governing relations between the States. ${ }^{3}$

2 The race to the bottom is used to describe government deregulation of the business environment, or reduction in tax rates, in order to attract or retain economic activity in their jurisdictions. In the case of refugee law, the States compete with each-other in order to attract less persecuted individuals.

3 In hierarchical order, the criteria are: from family considerations, to recent possession of visa or residence permit in a Member State, to whether the applicant has entered the EU irregularly, or regularly. However, in practice, the most used rule is the first country of entry. 
The second argument is the creation of equal conditions of competition. While this argument has been highly used in competition law (Doleys, 2012; Brittan, 1996), it has also been advocated for in recent decades in other fields of law, advancing a level of harmonisation for any kind of legislation within Europe (Faure, 2011). For instance, Article 9 of the Asylum Procedures Directive recognises the 'Right to remain in the Member State pending the examination of the application', while Article 46 establishes 'The right to an effective remedy' for all asylum seekers within Europe. The disparity between the recognition of these rights might create unequal conditions for competition between the EU Member States, which may directly or indirectly impact the functioning of the common market in a negative manner.

The third is the role of the EU as a sui generis organisation protecting human rights (Von Bogdandy, 2000). With regards to the protection of human rights, the international system has moved beyond State values towards respecting and protecting human values (Henkin, 1995). In other words, this argument deals with human rights. There are several EU policies safeguarding the protection of human rights. A clear example of this is the Charter of Fundamental Rights of the European Union of 2000, which became legally binding with the Lisbon Treaty coming into force in December 2009.

The EU asylum policy - where the EU has shared authority - has been stressed through the explicit reference of the subsidiarity principle in the Maastricht Treaty of 1992 and has also been recognised in the Lisbon Treaty. This paper considers the principle of subsidiarity as an economic demarcation principle regarding the distribution of competencies (Van den Bergh 1998), examining it as a double-edged concept considering both the increased centralisation and the expansion of the lower level of governance (Lenaerts and van Ypersele, 1994). As is already well-established, the principle of subsidiarity might lead to gains as well as losses through entailing diverse consequences with regards to efficiency (Gareth, 2005).

\section{THE NEED FOR CENTRALISATION OR DECENTRALISATION OF ASYLUM POLICY}

The analysis of the advantages or disadvantages of a common EU asylum law takes into consideration the Tiebout argument (Tiebout, 1956) and the problem of the 'race to the bottom', in addition to the prisoner dilemma, the reduction of transaction costs, and the importance of the protection of human rights. Moreover, it reflects on the protection of refugee rights through the implementation of equal treatment within the EU Member States.

\section{Tiebout theory}

The Tiebout argument is used to understand the optimal provision of local public goods (Tiebout, 1956). His basic premise is that citizens have different preferences. However, individuals with the same preferences will cluster together in small local communities, which leads to competitive legal systems, leading to 'allocative efficiency' under certain restrictive conditions.

For instance, if the majority of a group of locals prefer to build a stadium and another group of citizens aims to build a theatre, a stadium will probably be provided in the first community and the second community may fulfil its preference for the arts over sport. As a result, well-informed citizens will move from one community to the other according to their personal preferences. In other words, Tiebout assumes that citizens have different preferences and they are well-informed. Thus, citizens whose preferences have not been fulfilled will move from one community to another, which will satisfy their preferences.

In the Tiebout model, information plays an important role since using information accordingly will facilitate the move from one legal system to another. In addition, in order to maximise voter utility and minimise political costs, the most efficient solution exists at the time where heterogeneous voters' preferences are so varied that they do not overlap (Cremer et al., 1994). In the case of centralisation of normative rules, political costs increase since it is impossible to fulfil the heterogeneity of preferences (Ribstein and Kobayashi, 2006). Thus, the level of government deciding to rule should be the one 'enjoying a comparative advantage in accounting for the diversity of preferences in its choice of service delivery' (Estache, 1995).

In addition to limiting political costs, decentralisation has three other advantages: the evolutionary efficiency, the generation of a learning process and the speed of modifying a certain rule that is considered inefficient. Firstly, competition between legal systems might bring a sort of Darwinian evolution where only the most efficient rules survive (Zywicki, 2003). Comparative Law 
and Economics scholars highlight the importance of evolutionary efficiency as the main argument for the transplantation of foreign laws into the national system (Smits, 2002; Ogus, 1999; Mattei, 11994). Therefore, the most efficient rules will survive in addition to being transplanted into other legal systems. On the contrary, if the deciding authority is centralised and voters have heterogeneous preferences, the result of the law will be suboptimal compared to the decentralised decision-making model (Breuss, 2004).

The second advantage is that decentralisation hastens innovation in policy-making, since it gives agents the opportunity to choose the legal system that fits their needs (Parisi, 1998; Vihanto, 1992). Therefore, economic agents send a message to lawmakers through their choices (Snell and Andenas, 1999), giving a disciplinary effect to the regulatory competition between legal orders (Portuese, 2010) and pushing lawmakers to discover new rules that might be more efficient than the current local ones (Snell and Andenas, 1999).

Additionally, in the case of asymmetric information, competition between legal orders would be more desirable (Kay and Vickers, 1990). This is the case where the 'supplier' side has more information than the others. Thus, the disadvantages of asymmetrical information among policy makers and economic agents will somehow be compensated by regulatory competition between legal orders, since this grants hidden information to lawmakers (Oates 1999). According to the literature, the main costs in designing regulations are information costs (Portuese, 2010). In general, the costs for drafting, controlling, and implementing different policies is higher for the central government than the aggregate sum of the costs incurred by the local governments for doing so. This is a direct consequence of the 'knowledge problem' (Hayek, 1945).

The third advantage is that harmonised rules placed by central authorities can be difficult to change, since, in general, central systems can suffer from 'gigantism' (Woolcock, 1994; Schmidt, 1991). Furthermore, agreeing on a new decision might prove more difficult since there will be costly negotiations and compromises (Pelkmans, 1990). The modification becomes harder when the number of members is higher and there exists a heterogeneity of preferences (Buga, 2015). This might be the case in the recent failure to adopt a refugee quota system, where Eastern European countries, which do not receive a substantial number of applications for asylum protection, opposed its implementation (Zaun, 2018; Thielemann, 2918).

The Tiebout theory in favour of competition between legal systems gives perfect, positive advantages only if the subject to be regulated is a problem that does not exceed the borders of a community. On the contrary, when a problem contains an international feature, or the decision of a country has an impact on another, there might be an economies-of-scale argument. In this case, a centralised legislative body gives better results since it decreases or eliminates altogether the horizontal externalities (Bureau, 1992). In other words, there is a correspondence between the authority that has the jurisdiction to rule and the subject. Thus, if the subject is to be adjudicated crosses the national borders of the regulatory authority, the decision should be made at a higher regulatory level (Ogus, 1999).

According to the Tiebout theory, the optimal level of ruling is the national level. In simple words, decentralisation delivers gains in efficiency, unless there exists economic criteria that justify centralisation as a better alternative (Tiebout, 1956). In addition, decentralisation should take priority even if centralisation might bring benefits in terms of limiting potential free-riding by national lawmakers (Bureau and Champsaur, 1992). However, the public choice theory (Buxbaum, 1991; Porter, 1990) suggests that centralisation will be prioritised if social values - for example, the protection of vulnerable groups such as refugees - are involved, since the competition between legal systems may result in lowering their human rights standards by leading to an elimination of competitive advantages in the long run (Reich, 1992).

The notion of competition between legal systems also plays an important role in asylum law. As stated before, the State's individual choice entails positive or negative externalities for third countries because it directly affects the flow of migration (Bubb et al., 2011). These externalities and the supranational character of the refugee crisis is an important factor for an EU qualification. As the literature suggests, the competition between legal orders would be entirely inappropriate in the case of transfrontier externalities, since the costs and benefits of an action fall to different States (Snell 2000). A combination of EU asylum law - such as the Reception Conditions Directive and the Qualification Directive, the Asylum Procedures Directive and the Dublin Regulation - fits the economic criterion for community action (Asplund, 2003).

Coasean bargaining between countries that receive a lot of asylum applications and potential relocation countries for persecuted individuals could lead to the negotiation of an agreement between them (Van den Bergh, 2000). From an economic perspective, the two main transfer systems are north-to-south and south-to-south transfers (Bubb et al., 2011). In case of north-to-south transfers, refugees are moved from wealthy countries to poorer host countries; whereas in south-to-south transfers, which require the cooperation between poorer countries, there is a broader set of migration options for refugees. The south-to-south transfer 
system expands migration options for refugees. ${ }^{4}$ This approach generates positive outcomes for third countries since it eliminates the burden of directly hosting refugees. A complete and detailed investigation of it has recommended that if the costs of hosting refugees are convex, then it will be more efficient not to host large concentrations of refugees in neighbouring countries. As a result, economic scholars have advocated a south-to-south transfer system since it reduces the total social costs of hosting refugees (Kremer et al., 2011). As a result of these agreements, centralisation is not needed. However, Coase's solution cannot work in the case of supranational problems (Faure, 2001).

The EU's institutional framework can provide the legal instruments to enforce these types of agreements. In addition, and more importantly, the risk of strategic behaviour (Faure, 2001) and the 'free-riding' incentive (Andreoni, 1988) decrease since EU Member States are repeat players. Besides, harmonisation becomes the most efficient answer to avoid strategic or non-cooperative behaviour among local lawmakers (Portuese, 2010), which in the case of refugee law, is seen as a shared policy or shared asylum burden (Thielemann, 2018). In 2007, the European Commission consider the logic of harmonising EU asylum policy as a burden-sharing instrument.

Moreover, the EU approach has achieved better results than all attempts towards bilateral agreements between the Member States (Faure, 2001), ${ }^{5}$ since the internalisation of externalities through bargaining is unreachable and an optimal Pareto distribution cannot be achieved (Wittman, 1979). Furthermore, in the case of refugee law, the premise of Tiebout, where each local government has free choice regarding which legal norms to implement, is not fulfilled since a decision of a state impacts the others (Bubb et al., 2011). The absence of free choice between competing parties may lead to the distortion of competition between legal orders (Reich, 1992).

Lastly, as previously stated above, according to the Tiebout theory, information plays an important role, and there must be no information deficiencies (Van den Bergh, 1994). Thus, according to the Tiebout theory, well-informed persecuted individuals will move to the country that provides the local services that are best suited to their personal preferences, increasing their net benefits. However, only one empirical study (Neumayer, 2005) shows that refugees have adequate information about economic variables, and there is clear evidence that economic factors matter on refugee decision making. Indeed, in general, the scientific literature suggests that destinations are determined not by personal choices but by the practicalities and demands of the situation that persecuted individuals face en route to the destination country (Van den Bergh, 1994).

In summary, the assumptions of the Tiebout theory that citizens are well informed or that lawmakers are free to choose a legal rule without any type of externalities or spill-over effects are rarely met in the real world (Van den Bergh, 1994). Therefore, more realistic conditions may justify further centralisation. This is also the case in asylum law.

\section{Race to the bottom}

There is an economic argument to regulate the asylum law at the EU level since there is a risk of a 'race to the bottom'.

In order to attract less persecuted individuals, the Western European countries have introduced restrictive asylum policies that have led to a regulatory 'race to the bottom' (Des Places, 2003) or policy overspill (Suriyakumaran and Tamura, 2015). More precisely, a prisoner dilemma situation could arise, eventually leading to ineffective legislation in terms of enactment or enforcement (Faure, 2001). An EU-wide capability, also in asylum law, might avoid any prisoner dilemmas (Van den Bergh, 1994).

The competition between legal orders to create advantages for individual States is an argument used in different fields of law (Van den Bergh, 1994), giving rise to the harmonisation of rules and standards under the guise of 'levelling the playing field to avoid distortions of competition' (Faure, 2001). Nevertheless, public choice scholars of federalism have argued that differentiated legal orders can also bring market integration (Frey, 1994). They have considered the Swiss (Frey, 1994) and the Canadian (Boodman, 1991) models. Therefore, market integration could be possible without having a complete harmonisation of all legal rules and

4 A concrete example of it is the previous case of compensation of Kenya in 1994. The Kenyan government agreed to accept money compensation in exchange of receiving teh Rwandan refugees who had fled to Congo.

5 For instance, the case of pollution water provided to Dutch victims by a Belgium firm (Pasques 1996) since the negotiations between the two countries were going longer without having a positive result. 
standards (Revesz, 1992). Thus, centralisation is needed when the differences between legal systems might create an environment not conducive to competition.

The analogous application of the economic literature regarding public law that also concern topics that create externalities for other countries, such as environmental issues (Van den Bergh, 1994), might suppose that the 'race to the bottom' poses a problem if it is clear that the total cost of refugees will be different between the Member States. Therefore, an EU capability should exist. In other words, the 'race to the bottom' argument constitutes a problem if the competition between countries leads to an inefficient result. This is supported by one empirical study (Rotte, 1996), whose findings demonstrated the French restrictive asylum policy of 1991 led to the amendment of the German constitution of 1993. This then resulted in the enactment of a stricter asylum policy of the Great Britain in 1994.

Due to the increase of populism in some European countries such as France (Rydgren, 2008; Rydgren, 2003; Biorcio, 1991), ${ }^{6}$ Austria (Heinisch, 2008; Betz, 2001), ${ }^{7}$ and recently in Italy (Mammone, 2009; Betz, 2001; Biorcio, 1991), ${ }^{8}$ Europe might face a 'race to the bottom' because the recent anti-immigration sentiment among the European constituents in the political spectrum (Alonso and da Fonseca, 2012; Howard, 2010). According to the public choice theory, politicians tend to maximise their own utility (Frey and Lau, 1968). Thus, since there is an increase in populism, politicians who aim for the maximisation of their own utility will establish even more restrictive asylum rules.

To sum up, in the case of refugee law, the 'race to the bottom' theory is an important argument for centralisation. The increase in populism in some European countries may lead to a further prominence of the 'race to the bottom' theory in asylum law.

\section{Reduction of transaction costs}

The EU capability has been revered due to the fact that harmonisation reduces transactional costs (Rose-Ackerman, 1993). This is particularly the case in private law since diverse laws increase costs for international firms (Commission on European Contract Law). In public law, some authors have discussed the idea of transaction costs (Ruiter, 2005; Van Kersbergen and Van Waarden, 2001; Dixit, 1984; Williamson, 1981), which include not only economic activities but also any kind of social activities involving transaction costs (Ruiter, 2005).

The reduction of transaction costs has been an important argument for the centralization of rules by EU's institutions. According to this model, uniform rules may reduce information costs incurred by their legal systems since reconciliation of rules is no longer required. However, this argument is weak for two main reasons. First, legal uncertainty might not be reduced even if there are uniform rules because EU Member States use different languages. Additionally, judges in different jurisdictions may not conduct a uniform interpretation, in order to either gain prestige or lower work pressures (Van den Bergh, 2000). Second, there is no empirical evidence that uniform rules decrease transaction costs (Van den Bergh and Visscher, 2006). Although significant and large economic agents will not consider adaptation costs to a new legal system as an important factor when deciding whether to enter a new market (Wagner, 2002), transaction costs are an important factor in the case of natural persons, who will spend time and energy to better understand the differences between legal orders (Siebert, 1993).

The reduction of transaction costs plays a particular role in the case of the 'negative harmonisation' (harmonisation without the need of an international instrument) (Aldana, 2013). In the case of asylum law, spontaneous cooperation in international refugee law has been inefficient (Bouteillet-Paquet, 2003). This is due to the fact that spontaneous convergence has more advantages than the formal harmonisation only in the branches of law, where it is economically appropriate; in other words, where the benefits of convergence exceed its costs (Leebron, 1995). As it was stated above, countries have continuously restricted their national refugee policies by also adopting similar restrictive policies of other countries (Rotte et al., 1996).

\footnotetext{
6 It should be mentioned that on 23 April 2017, no candidate won a majority in the first round and Marine Le Pen of the National Front (FN) was the second candidate to win the presidential elections.

7 It should be mentioned that on 15 October 2017, the Austrian People's Party emerged as the largest party in the National Council.
}

8 It should be mentioned that the new Italian government formed in May 2018 is also led by one of the populism parties (Lega). Furthermore, in May 2019, in the European Election, the Lega Party won the highest number of seats. 
Ultimately, in a field where transaction costs pose substantial problems in integration, harmonisation is needed (Snell and Andenas, 1999). In particular, the centralisation of asylum law at an EU level will bring about a decrease of transaction costs for two main reasons. First, transaction costs are an important factor in the case of natural persons (Siebert and Koop, 1993), as the persecuted individuals are. Second, transaction costs play a particular role in the case of 'negative harmonisation' (Aldana, 2013), as it has happened in the case of refugee law in Western European countries in the last few decades (Des Places, 2003).

\section{Protection of Human Rights}

This paper examines as well the role of the $\mathrm{EU}$ as a sui generis organisation protecting human rights. Although this is not an economic argument, some observations are to be noted.

The EU was created to unite the European countries economically and politically in order to secure lasting peace (the European Union). In 1957, the six founding countries (Belgium, France, Germany, Italy, Luxembourg, and the Netherlands) created the European Economic Community or the 'Common Market'. Soon after, in the late 1960s, the protection of human rights was also part of the European agenda (Von Bogdandy, 2000), with aspirations to create 'Europe with a Human Face'. This transformation occurred in stages. ${ }^{9}$ However, during the first decades, the protection of human rights through EU institutions was possible solely through the application of Article 100 of the Treaty of Rome. ${ }^{10}$

With respect to refugee law, asylum cooperation formally started with the Amsterdam Treaty of 1999, which was a response to the Kosovo refugee crisis (Lavenex, 2001). The current Article 78 of the TFEU states 'the Union shall develop a common policy on asylum, subsidiary protection and temporary protection' by enhancing the EU role in the asylum law. In adherence to it, the EU has switched from a non-binding and voluntary mechanism to the binding mechanism of recent years (Thielemann, 2018). Thus, in June of 2017, the European Commission launched a legal case against Poland, Hungary and the Czech Republic for non-compliance with their legal obligations on relocation (European Commission, 2017).

In addition to the protections recognised in Article 78 of the TFEU, the role of the EU has not stopped merely at the protection of 'refugees' or individuals falling under the category of 'subsidiary protection' but has further considered the possibility of integrating visa issuance for humanitarian reasons. In order to do so, there were studies such as those for the European Commission back in 2002, the Green Paper on Asylum in 2006, the Stockholm Programme of 2009, and a Communication on An Open and Secure Europe in 2014..$^{11}$

In short, although cooperation between the Member States was a central aim since the creation of a common market, from the late 1960s, EU institutions endeavoured to create 'Europe with a Human Face'. This was codified in the Amsterdam Treaty of 1999 and also in the current Article 78 of the TFEU. Although this factor is not an economic argument, it is nevertheless a legal one applying a human rights approach.

\footnotetext{
9 Some good examples of this goal in the early 1970s are: Declaration by the Heads of Government of the Member States meeting in Paris in 1972 (Bull. EC 10-1972: The First Summit Conference of the Enlarged Community 19-20 Oct. 1972). Cf. Declaration of the Council of the European Communities and of the Representatives of the Governments of the Member States on the Programme of Action of the European Communities on the Environment O.J. 1973, C 112/1; Council Resolution concerning a social action programme O.J. 1974, C 13/1; Council Resolution on a preliminary programme of the European Economic Community for a consumer protection and information policy O.J. 1975, C 92/1.

10 Article 100 of the Treaty Establishing the European Community states: 'The Council shall, acting unanimously on a proposal from the Commission, issue directives for the approximation of such provisions laid down by law, regulation or administrative action in Member States as directly affect the establishment or functioning of the common market. The Assembly [European Parliament] and the Economic and Social Committee shall be consulted in the case of directives whose implementation would, in one or more Member States, involve the amendment of legislation.'
}

11 However, neither the guidelines nor the coordinated approach have ever been materialized. 


\section{CONCLUSION}

This paper examines the principle of subsidiarity within asylum law. It aims to better understand the extent of EU power in asylum law in addition to exposing the advantages and disadvantages of decentralised decision making by looking at the criteria of economic efficiency.

This paper considers significant legal reasoning, public choice literature, and the economic analysis of legal integration without being comprehensive of all types of economic theories. Its central research question deals with the topic of allocative efficiency by comparing the static economic analysis of the Tiebout theory with the dynamic view of competition between legal orders.

The presumptions of the Tiebout argument in favour of competition between legal orders are (1) a large number of suppliers of legal rules, (2) no information deficiencies, and (3) no externalities, which brings along a problem with economies of scale. While the first requirement in asylum law in the EU context might be considered fulfilled, the other two are not. Neither the refugees nor the single States have adequate information needed to make the decision. In general, according to the literature, asylum seekers know nothing or have little information regarding the final destination country (Havinga, 1999). In addition, the States do not perfectly possess all the information about the preferences of all persecuted individuals regarding the decision of the final destination country. Moreover, the individual's choice of destination entails positive or negative externalities for third countries because it directly affects the flow of migration (Bubb et al., 2011).

The EU's authority in asylum law has two other advantages. First, the centralisation of law leads to the reduction of transaction costs, which plays a particular role in the case of 'negative integration'. Indeed, in the case of refugee law, spontaneous cooperation in international refugee law has been inefficient. As stated, countries have continuously restricted their national refugee policies by adopting similar restrictive policies of other countries. Second, the EU authority in asylum law aims to standardise the protection of refugee rights within the EU Member States. This new strategy has been in the EU agenda since the late 1960s.

However, a total EU capability in asylum law without legal competition between EU Member States will increase sovereignty costs, while therefore, fully pre-empting national capabilities to take independent actions. In addition, given the heterogeneous preferences of different EU Member States, a full harmonisation should remain an ultimum remedium (Van den Bergh, 1994). Moreover, the results of the dynamic approach to the competition between legal orders should be considered (Van den Bergh, 1994). While the EU institutions shall organise competition between the laws of the EU Member States, the sovereignty costs should be as limited as possible.

A strategy that considers both the advantages and disadvantages of the centralisation of refugee law is the minimum standard. In other words, in refugee law, a mixed system where States can still compete but cannot go under a certain level of protection might be a good choice. Thus, the integration of laws and competition between legal rules are not necessarily mutually exclusive (Van den Bergh, 2000).

In conclusion, this paper investigated the principle of subsidiarity in asylum law by considering the advantages and disadvantages of decentralised decision making. After reviewing the selected essential theories, it concludes that a strategy that considers both the advantages and disadvantages of the centralisation of refugee law is the minimum standard for integration. This policy is also in accordance with the evolution of EU law and the principle of subsidiarity established in the Treaty of Amsterdam, which aimed to increase the community's capabilities and offer more autonomy to Member States (Reich, 1992).

\section{Acknowledgment}

This paper is realized with the support of Erasmus+ Programme of the European Union. PhD Denard Veshi is the winner of Jean Monnet Module in Refugee Law 2017-2020 (587001-EPP-1-2017-1-AL-EPPJMO-MODULE) and of Erasmus+ Jean Monnet EU Center of Excellence 2019-2021 (610495-EPP-1-2019-1-AL- EPPJMO-CoE). 


\section{REFERENCES}

Aldana, J. M. B. (2013). La armonización del Derecho, concepto y críticas en cuanto a su implementación. Revista e-mercatoria 12(2), 80-139.

Alonso, S., and S. C. da Fonseca. (2012). Immigration, left and right. Party Politics 18(6), 865-884.

Andreoni, J. (1988). Why free ride?: Strategies and learning in public goods experiments. Journal of public Economics 37(3), 291-304.

Asplund, E. (2003). A Study of the Development of the Asylum Law and Policy of the European Union with Focus on the Role of Burden-Sharing and Temporary Protection. (2003).

Bailliet, Cecilia. 'The Tampa Case and its Impact on Burden Sharing at Sea.' Human Rights Quarterly 25.3 (2003): 741-774.

Betts, A. (2003). Public goods theory and the provision of refugee protection: The role of the joint-product model in burden-sharing theory. Journal of Refugee Studies 16(3), 274-296.

Betz, H. (2001). Exclusionary Populism in Austria, Italy, and Switzerland. International Journal 56(3), 393-420.

Biorcio, R. (1991). The Rebirth of Populism in France and Italy.

Boodman, M. (1991). The myth of harmonization of laws. The American Journal of Comparative Law 39(4), 699-724.

Bouteillet-Paquet, D. (2001). L'Europe et le droit d'asile. Editions L'Harmattan.

Breuss, F., and Eller, M. (2004). The optimal decentralisation of government activity: normative recommendations for the European constitution. Constitutional Political Economy 15(1), 27-76.

Brittan, L., and Miert, K. V. (1996). Towards an international framework of competition rules. International Business Law 24, 454.

Bubb, R., Kremer M., and Levine D. I. (2011). The economics of international refugee law. The Journal of Legal Studies 40(2), 367-404.

Buga, I. (2015). The Modification of Treaties by Subsequent Practice: The Implications of Practice Going Beyond the Limits of Treaty Interpretation. Diss. University Utrecht.

Bureau, D., and Champsaur P. (1992). Fiscal federalism and European economic unification. The American Economic Review 88-92.

Buxbaum, R. M., Hirsch A., and Hopt, K. eds. European business law: Legal and Economic analyses on integration and harmonization. Walter de Gruyter, 1991.

Card, David. 'The impact of the Mariel boatlift on the Miami labor market.' ILR Review 43.2 (1990): 245-257.
Choi, Seung-Whan, and Idean Salehyan. 'No good deed goes unpunished: refugees, humanitarian aid, and terrorism.' Conflict Management and Peace Science 30.1 (2013): 53-75.

Commission on European Contract Law, (1994). https://www.jus.uio. no/lm/eu.principles.lando.commission/doc.html (on-line in November 2018)

Committee of the UN, Committee against Torture, United States, CAT/C/ USA/CO/2, 25 July 2006.

Cortes, Kalena E. 'Are refugees different from economic immigrants? Some empirical evidence on the heterogeneity of immigrant groups in the United States.' Review of Economics and Statistics 86.2 (2004): 465-480;

Cortes, Kalena E. 'Are refugees different from economic immigrants? Some empirical evidence on the heterogeneity of immigrant groups in the United States.' Review of Economics and Statistics 86.2 (2004): $465-480$.

Cremer, J., Estache A., and Seabright, P. (1994). The decentralization of public services: lessons from the theory of the firm. Vol. 1345. World Bank Publications.

Day, Kate, and Paul White. 'Decision making or circumstance: The UK as the location of asylum applications by Bosnian and Somali refugees.' GeoJournal 56.1 (2002): 15-26.

Des Places, S. B. (2003) Evolution of asylum legislation in the EU: insights from regulatory competition theory. No. 16. European University Institute (EUI), Robert Schuman Centre of Advanced Studies (RSCAS), 2003.

des Places, Ségolène Barbou, and Bruno Deffains. 'Cooperation in the shadow of regulatory competition: the case of asylum legislation in Europe.' International Review of Law and Economics 23.4 (2003): 345364 .

Dixit, A. K. (1998). The making of economic policy: A transaction-cost politics perspective. MIT press.

Doleys, T. J. (2012). Promoting competition policy abroad: European Union efforts in the developing world. The Antitrust Bulletin 57(2), 337366 .

Dustmann, Christian. 'Differences in the labor market behavior between temporary and permanent migrant women.' Labour Economics 4.1 (1997): 29-46; Rivera-Batiz, Francisco L. 'English language proficiency and the economic progress of immigrants.' Economics Letters 34.3 (1990): 295-300. 
Ellickson, R. (1979). C. Public property rights: Vicarious intergovernmental rights and liabilities as a technique for correcting intergovernmental spillovers.

Estache, A., ed. (1995). Decentralizing infrastructure: Advantages and limitations. The World Bank, 1995.

Esty, D. C., and Geradin, D. (2001). Regulatory competition and economic integration: comparative perspectives. Oxford University Press.

Esty, Daniel C., and Damien Geradin. Regulatory competition and economic integration: comparative perspectives. Oxford University Press, 2001.

European Commission (2007) 'Green Paper on the Future Common Asylum System', COM (2007) 301 final, July 2010.

European Commission, 2017, Relocation: Commission refers the Czech Republic, Hungary and Poland to the Court of Justice http://europa.eu/ rapid/press-release_IP-17-5002_en.htm (on-line in November 2018)

European Court of Justice, Judgment in Joined Cases C-391/16, C-77/17 and $\mathrm{C}-78 / 17$

European Court on Human Rights Application nos. 3394/03, 55721/07, and also confirmed by the no. 27765/09

European Union, The Founding Fathers of the EU https://europa.eu/ european-union/about-eu/history_en (on-line in July 2019)

Faure, M. (2001). 'Regulatory Competition vs Harmonization in EU Environmental Law' in Esty, Daniel C., and Damien Geradin. Regulatory competition and economic integration: comparative perspectives. Oxford University Press.

Fernández-Huertas Moraga, Jesús, and Hillel Rapoport. 'Tradable refugee-admission quotas and EU asylum policy.' CESifo Economic Studies 61.3-4 (2015): 638-672.

Fischer-Lescano, Andreas, Tillmann Löhr, and Timo Tohidipur. "Border controls at sea: Requirements under international human rights and refugee law." International Journal of Refugee Law 21.2 (2009): 256-296.

Frey, B. S. (1994). Direct democracy: politico-economic lessons from Swiss experience. The American Economic Review 84(2), 338-342.

Frey, B., and Lau. L. J. (1968). Towards a mathematical model of government behaviour. Zeitschrift für Nationalökonomie 28 (3-4), 355-380.

Gareth, T. D. (2005). Subsidiarity as a Method ofPolicy Centralisation14 (Int'l Law Forum of the Hebrew Univ. of Jerusalem, Research Paper 11-06, 2005), available at http://papers.ssm.com/sol3/ papers. cfm?abstractid-921454 (on-line in September 2018)

Gilbert, Alan, and Khalid Koser. 'Coming to the UK: what do asylumseekers know about the UK before arrival?.' Journal of ethnic and migration studies 32.7 (2006): 1209-1225.
Hathaway, James C. The rights of refugees under international law. Cambridge University Press, 2005.; Guy S. Goodwin-Gill, and Jane McAdam. 'The Refugee in International Law.' (2007): 2-11.

Havinga, T., and Böcker, A. (1999). Country of asylum by decision making or by chance: Asylum-seekers in Belgium, the Netherlands and the UK. Journal of ethnic and migration studies 25(1), 43-61.

Hayek, F. A. (1945). The use of knowledge in society. The American economic review 35(4), 519-530.

Heinisch, R. (2008). Right-wing populism in Austria: A case for comparison. Problems of Post-Communism 55(3), 40-56.

Henkin, L. (1995). International law: politics and values. Developments in International Law 18.

Howard, M. M. (2010). The impact of the far right on citizenship policy in Europe: explaining continuity and change. Journal of Ethnic and Migration Studies 36(5), 735-751.

Kay, J. A., and Vickers, J. S. (1990). Regulatory reform: An appraisal, [w:] G. Majone (ed.), Deregulation or Re-regulation.

Koka, Enkelejda, and Denard Veshi. 'Irregular Migration by Sea: Interception and Rescue Interventions in Light of International Law and the EU Sea Borders Regulation.' European Journal of Migration and Law 21.1 (2019): 26-52.

Kremer, M, Bubb, R. and Levine, D. (2011). The Economics of International Refugee Law. Journal of Legal Studies 40(2).

Lauterpacht, Elihu, and Daniel Bethlehem. 'The scope and content of the principle of non-refoulement: Opinion.' Refugee protection in international law: UNHCR's global consultations on international protection (2003).

Lavenex, S. (2001). The Europeanization of refugee policies: Normative challenges and institutional legacies. JCMS: Journal of Common Market Studies 39(5), 851-874.

Leebron, D. W. (1995). Lying down with Procrustes: An analysis of harmonization claims. Center for Law and Economic Studies, Columbia University School of Law.

Lenaerts, K., and van Ypersele, P. (1994). Le principe de subsidiarité et son contexte: étude de I'article $3 \mathrm{~B}$ du Traité CE.Cahiers de droit européen 30(1), 3-85.

Mammone, A. (2009). 'The eternal return? Faux populism and contemporarization of neo-fascism across Britain, France and Italy.' Journal of contemporary European studies 17(2), 171-192;

Mattei, U. (1994). Efficiency in legal transplants: An essay in comparative law and economics. International Review of Law and Economics 14(1), 3-19. 
Milton, Daniel, Megan Spencer, and Michael Findley. 'Radicalism of the hopeless: Refugee flows and transnational terrorism.' International Interactions 39.5 (2013): 621-645.

Moe, T. M. (1984). The new economics of organization. American journal of political science $739-777$.

Mogire, Edward. 'Refugee realities: Refugee rights versus state security in Kenya and Tanzania.' Transformation 26.1 (2009): 15-29.

Monheim-Helstroffer, Jenny, and Marie Obidzinski. 'Optimal discretion in asylum lawmaking.' International Review of Law and Economics 30.1 (2010): 86-97.

Neumayer, E. Bogus refugees? The determinants of asylum migration to Western Europe. International studies quarterly 49(3), 389-410.

Neumayer, Eric. 'Bogus refugees? The determinants of asylum migration to Western Europe.' International studies quarterly 49.3 (2005): 389-410.

Oates, W. E. (1999). An essay on fiscal federalism. Journal of economic literature 37(3), 1120-1149.

Ogus, A. (1999). Competition between national legal systems: a contribution of economic analysis to comparative law. International \& Comparative Law Quarterly 48(2), 405-418.

Parisi, F., and Ribstein L. (1998). 'Choice of law.' The new Palgrave dictionary of economics and the law 1, 236-241.

Pelkmans, J. (1990). Regulation and the single market: An economic perspective. The completion of the single market, Mohr: Tuebingen.

Porter, M. E. (1990). The competitive advantage of nations. Competitive Intelligence Review $1(1), 14-14$.

Portuese, A. (2010). The principle of subsidiarity as a principle of economic efficiency. Columbian Journal European Law 17, 231.

Price, M. E. (2009). Rethinking asylum: History, purpose, and limits. Vol. 92. Cambridge: Cambridge University Press.

Randahl, D. A. V. I. D. 'Refugees and Terrorism.' PAX et Bellum Journal 3.1 (2016): 46-56.

Reich, N. (1992). Competition between legal orders: A new paradigm of EC law. Common Market Law Review 29, 861.

Revesz, R. L. (1992). Rehabilitating interstate competition: Rethinking the race-to-the-bottom rationale for federal environmental regulation. NYUL Review 67, 1210.

Ribstein, L., and Kobayashi B. (2006). The economics of federalism. http://citeseerx.ist.psu.edu/viewdoc/ download?doi=10.1.1.563.8018\&rep=rep1\&type=pdf (on-line in November 2018)
Roberts, Anthea. 'Righting wrongs or wronging rights? The United States and human rights post-September 11.' European Journal of International Law 15.4 (2004): 721-749.

Rose-Ackerman, S. (1993). Rethinking the progressive agenda. Simon and Schuster.

Rosholm, Michael, and Rune Vejlin. 'Reducing income transfers to refugee immigrants: Does start-help help you start?.' Labour Economics 17.1 (2010): 258-275.

Rotte, R., V., Zimmermann, K.F.( 1996). Asylum migration and Policy coordination in Europe, Dicussion Papers, Munchener Wirtschaftswissenschaftliche Beitrage, 96-11, July 1996.

Ruiter, D. WP. (2005). Is transaction cost economics applicable to public governance?. European journal of law and economics 20(3), 287-303.

Rydgren, J. (2003). Meso-level reasons for racism and xenophobia: Some converging and diverging effects of radical right populism in France and Sweden. European Journal of Social Theory 6(1), 45-68.

Schmidt, H. (1991). Economic Analysis of the Allocation of Regulatory Competence in the European Communities in R.M. Buxbaum, G. Hertig, A. Hirsch and K.J. Hopt (eds.), European Bvsincss Law. Legal and Economic Anulyses on Infegralion and Harmonizalion (Berlin 1991)

Siebert, $\mathrm{H}_{\text {., }}$ and KoopJ. M. Institutional competition versus centralization: quo vadis Europe?. Oxford Review of Economic Policy 9(1), 15-30.

Smits, J. M. How to Predict the Differences in Uniformity between Different Areas of a Future European Private Law? An Evolutionary Approach. The Economics of Harmonizing European Law. Edward Elgar Publishing.

Snell, J. (2000). True proportionality and free movement of goods and services. European Business Law Review 11, 50.

Snell, J., and Andenas, M. (1999). Exploring the Outer Limits-Restrictions on the Free Movement of Goods and Services. European Business Law Review 10, 252.

Suriyakumaran, A. and Tamura J. (2015). Asylum provision: A review of economic theories. International Migration.

Thielemann, E. (2018). Why Refugee Burden-Sharing Initiatives Fail: Public Goods, Free-Riding and Symbolic Solidarity in the EU. JCMS: Journal of Common Market Studies 56(1), 63-82.

Tiebout, C. M. (1956). A pure theory of local expenditures. Journal of political economy $64(5), 416-424$.

UNHCR (1997) EXCOM Conclusion on Safeguarding Asylum No. 82 (XLVIII).

UNHCR (2004) EXCOM General Conclusion No. 90 (LV), 2004. 
UNHCR (2007) Advisory Opinion on the Extraterritorial Application of Non-Refoulement Obligations under the 1951 Convention relating to the Status of Refugees and its 1967 Protocol, 26 January.

Van den Bergh, R. (1998). Subsidiarity as an economic demarcation principle and the emergence of European private law. Maastricht Journal of European and Comparative Law 5(2), 129-152.

Van den Bergh, R. (2000). Towards an Institutional Legal Framework for Regulatory Competition in Europe. Kyklos 53(4), 435-466.

Van den Bergh, R. The subsidiarity principle in European Community law: some insights from law and economics. Maastricht Journal of European and Comparative Law 1(4), 337-366.

Van den Bergh, R., and Visscher L. (2006). The Principles of European Tort Law: The Right Path to Harmonisation? German Working Papers in Law and Economics 8.

Van Kersbergen, K., and Van Waarden, F. (2001). Shifts in governance: Problems of legitimacy and accountability. Study for the Dutch Research Council (unpublished).

Vihanto, M. (1992). Competition between local governments as a discovery procedure. Journal of Institutional and Theoretical Economics (JITE)/Zeitschrift für die gesamte Staatswissenschaft 411-436.

Von Bogdandy, A. (2000). European Union as a Human Rights Organization-Human Rights and the Core of the European Union. The Common Market Law Review 37, 1307.

Wagner, G. 2002. The economics of harmonisation: The case of contract law. ERA Forum. Vol. 3. No. 2. Springer-Verlag,

Williamson, O. E. (1981). The economics of organization: The transaction cost approach. American journal of sociology 87(3), 548-577.

Wittman, D. (1989). Why Democracies Produce Efficient Results, 97 J. Political Economics 1395, 1407-08.

Woolcock, S. (1994). The single European market: centralization or competition among national rules?. London: Royal Institute of International Affairs.

Zaun, N. (2018). States as Gatekeepers in EU Asylum Politics: Explaining the Non-adoption of a Refugee Quota System. JCMS: Journal of Common Market Studies 56(1), 44-62.

Zywicki, T. (2003). The Rise and Fall of Efficiency in the Common Law: A Supply-Side Explanation. Paul H. Rubin \& Samuel. 